\title{
Efficient highly productive new meat cross Smena-9 with federsex maternal parental form
}

\author{
Zh.V. Emanyilova ${ }^{1}, A . V$. Egorova $^{2, *}$, D.N. Efimov ${ }^{2}$, and A.A. Komarov ${ }^{1}$ \\ ${ }^{1}$ Selection Genetic Centre "Smena", branch of Federal Scientific Center "All-Russian Research and Technological Poultry Institute" of \\ Russian Academy of Sciences, 141357 Russia, Moscow Region, Bereznyaki village, 117 \\ ${ }^{2}$ Federal Scientific Center “All-Russian Research and Technological Poultry Institute” of Russian Academy of Sciences, 141311 Russia, \\ Moscow Region, Sergiev Posad, Pticegradskaya Str., 10
}

\begin{abstract}
The paper assesses the efficiency of using the federsex for marker genes K-k maternal parental form and the final broiler hybrid of the new highly productive cross Smena-9 in production conditions. It was found that two-lined chickens of the maternal parental form SM79 have an advantage over the original lines in reproductive qualities (egg production, hatching eggs, hatching, number of chickens per a laying hen) by 1.23-25.6\%. Under optimal conditions for feeding and keeping, 138.5 heads of day-old broilers can be obtained from the autosex maternal parental form. During selection of linear poultry, the following indicators of broilers were improved: livability, live weight, dressed weight, yield of pectoral muscles and reduced feed costs per $1 \mathrm{~kg}$ of live weight gain. The meat yield from one parental pair was $314.8 \mathrm{~kg}$. The taste qualities of broth and poultry meat of the Smena- 9 cross are high. The sexing accuracy is $99.8 \%$. Poultry of the federsex maternal parental form and the final hybrid - broilers of the new Russian cross Smena-9 has a high genetic potential and can be successfully used in the production of eggs and meat at enterprises of various types.
\end{abstract}

\section{Introduction}

Progress in broiler production, especially in the last decade, is driven by the high demand for relatively inexpensive, nutritionally valuable poultry meat, the presence of highly productive crosses and the high efficiency of this industry [1-3].

The efficiency of meat production depends not only on productivity indicators, but also on the genetic potential of the reproductive qualities of the parental forms. The main criterion in this case is the rate of broiler yield from one parent pair for a certain period of poultry use. This indicator depends on egg production for the initial laying hen, fertility and hatchability of eggs, the quality of hatched chickens. The yield of broiler chickens from one parental pair of crosses with a high increase in live weight reaches $140-145$ heads. To obtain such a number of chickens, it is necessary to receive 170-175 eggs in 64 weeks of life of laying hens when 160-165 eggs are used for incubation [1].

At the present stage of selection, the original lines are of great importance. Their productivity has an influence on the indicators of parental forms and broilers. Scientific and industrial experience in breeding meat chickens indicates the need for constant improvement of methods and techniques to increase the genetic potential of their breeding and productive qualities. This will allow one to breed new populations and use them as material for creating new highly profitable, competitive crosses in regions with different climatic and economic conditions.

An increase in the rate of increase in live weight of broilers was achieved due to intensive selection of the initial lines of meat chickens according to the indicators of this trait, as well as the use of sex-separate growing of chickens, the use of autosex forms $[2,4,5]$.

A systematic search for new combinations, used as parental forms or the final hybrid, makes it possible to improve the existing and create new lines, breeds, crosses for a shorter period of time and at lower costs $[4,6]$. Improvement of individual traits in the parental forms and the final hybrid can be achieved by replacing individual lines or parental forms. These problems can be solved by experimental crossing of various lines, and using new methods of selection $[2,4,6]$. Progress in the industry requires continual improvement in poultry.

In recent years, in breeding work, much attention has been paid to marker genes: silverness - goldenness, slow - fast feathering. Their use allows one to separate dayold chicks by sex and, as a result, to reduce production costs with high accuracy and speed [7-14].

This work aims to evaluate the efficiency of using federsex for marker genes maternal parental form and the final broiler hybrid of the new highly productive Russian cross Smena-9 in production conditions.

\footnotetext{
* Corresponding author: egorova@,vnitip.ru
} 
SM79 genotype Kk (slow feathering)
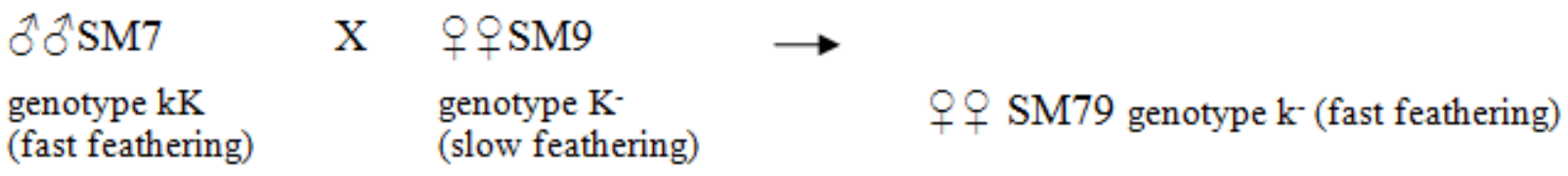

Fig. 1. Sheme.

\section{f SM56 79 genotype kk (fast feathering)}

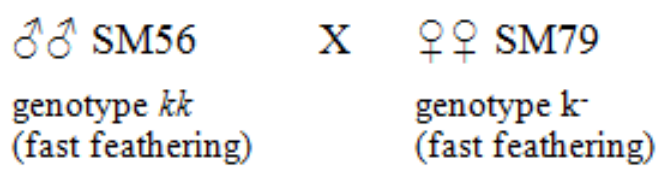

@ SM56 79 genotype k- (fast feathering)

Fig. 2. Sheme.

\section{Materials and methods}

To achieve the set goal, studies were carried out in the production conditions of the Selection Genetic Centre "Smena" (Moscow region) on maternal parental poultry and broiler chickens of the SM5679 combination of the Smena-9 cross.

The maternal parental form (1500 heads) and final hybrids (1500 heads) were examined. We used the chicken floor housing. Poultry feeding was carried out according to the norms used by the "Smena" SGC and in accordance with the recommendations [15]. The type of feathering was established visually for 1-day-old chickens. For slow feathering of the wing, the coverts are longer than flight feathers or equal to them. For fast feathering, the coverts are shorter than the flight feathers and are well developed. The meat quality of broilers was determined by carrying out anatomical cutting of carcasses according to the method [16]. The following indicators were taken into account: live weight at 35, 49 days of age; average daily gain in live weight; feed costs per $\mathrm{kg}$ of live weight gain; livability; dressed weight; pectoral muscle yield; abdominal fat content.

\section{Results and discussion}

The maternal parental form of the new cross Smena-9 is the two-lined form SM79, which is autosex for marker genes of slow and fast feathering.

It is obtained by crossing specialized highly productive lines of the Plymouth Rock breed according to the following scheme (fig. 1).

Cockerels SM79 from these lines crosses are grown for meat. To obtain the final hybrid (broilers), chickens of maternal parental form SM79 are crossed with maternal parental form SM56 roosters (fig. 2).

The line SM7 is the paternal line selected for a relatively higher rate of gain in live weight of young animals. The line SM9 is the maternal line selected for higher rates of reproductive qualities and rate of gain in live weight of young animals.

Purposeful selection of the SM7 line as the paternal and maternal SM9 line led to an improvement in the reproductive qualities of the two-lined form SM79 (Table 1).

Table 1. Economically useful qualities of the maternal parental form.

\begin{tabular}{|l|c|c|c|c|c|}
\hline \multicolumn{1}{|c|}{ Traits } & SM7 & SM9 & SM79 & $\begin{array}{c}\text { SM79 to } \\
\text { SM7, \% }\end{array}$ & $\begin{array}{c}\text { SM79 to } \\
\text { SM9, \% }\end{array}$ \\
\hline $\begin{array}{l}\text { Egg } \\
\text { production } \\
\text { of chickens } \\
\text { for 60 weeks } \\
\text { of life, pcs. }\end{array}$ & 147.0 & 162.0 & 164.0 & +11.6 & +1.23 \\
\hline $\begin{array}{l}\text { Hatchery egg } \\
\text { yield, \% }\end{array}$ & 94.5 & 94.7 & 96.2 & +1.7 & +1.5 \\
\hline $\begin{array}{l}\text { Hatching } \\
\text { chicks, \% }\end{array}$ & 77.0 & 80.6 & 85,2 & +8.2 & +4.6 \\
\hline $\begin{array}{c}\text { Number of } \\
\text { chickens per } \\
\text { hen, head }\end{array}$ & 107.0 & 124.0 & 134.4 & +25.6 & +8.4 \\
\hline
\end{tabular}

Table 1 shows that the two-lined maternal parental chickens of the SM79 form have an advantage over the original lines. It is explained by the effect of heterosis in reproductive traits.

The number of chickens per laying hen for the twolined maternal form SM79 is higher than that of singleline hens by 25.6 and $8.4 \%$, respectively, as compared to the lines SM7 and SM9.

The two-lined Plymouth Rock SM79 chickens have higher reproductive qualities, that indicates the compatibility of these lines. The productivity of meat chickens of maternal parental forms SM79 and B79 are presented in Table 2. 
Table 2. Productivity of maternal parental form SM79 hens of the cross Smena-9 in the conditions of the "Smena" SGC.

\begin{tabular}{|l|c|c|c|}
\hline \multirow{2}{*}{ Traits } & \multicolumn{2}{|c|}{ Cross } & \multirow{2}{*}{$\begin{array}{c}\text { SM79 to } \\
\text { B79, \% }\end{array}$} \\
\cline { 2 - 3 } & $\begin{array}{c}\text { Smena-9 } \\
\text { SM79 }\end{array}$ & $\begin{array}{c}\text { Smena-8 } \\
\text { B79 }\end{array}$ & +1.8 \\
\hline $\begin{array}{l}\text { Egg production of } \\
\text { chickens for 62 } \\
\text { weeks of life, pcs. }\end{array}$ & 169.0 & 166.0 & \\
\hline $\begin{array}{l}\text { Age of chickens } \\
\text { upon reaching: } \\
\text { - 50\% of egg laying, } \\
\text { days; }\end{array}$ & 184 & 187 & -1.6 \\
\hline $\begin{array}{l}\text { Egg mass, g for 30- } \\
\text { weeks chickens; }\end{array}$ & 58.5 & 58.1 & +0.69 \\
\hline $\begin{array}{l}\text { Hatchery egg yield: } \\
\text {-\% } \\
\text { - pcs. }\end{array}$ & 96.2 & 94.1 & +2.1 \\
\hline $\begin{array}{l}\text { The output of } \\
\text { chickens from one } \\
\text { parental pair, heads }\end{array}$ & 138.5 & 132.5 & +4.53 \\
\hline Hatching chicks, \% & 85.2 & 84.8 & +0.04 \\
\hline $\begin{array}{l}\text { Livability, \% } \\
\text { young chicken } \\
\text { - mature chicken }\end{array}$ & 97.1 & 96.2 & +0.9 \\
\hline $\begin{array}{l}\text { Meat yield from 1 } \\
\text { parent pair, when } \\
\text { slaughtering broilers } \\
\text { for 35 days, kg }\end{array}$ & 314.8 & 265.9 & +18.4 \\
\hline $\begin{array}{l}\text { The accuracy of } \\
\text { chick sexing, \% }\end{array}$ & 99.8 & - & +0.5 \\
\hline
\end{tabular}

Under optimal conditions, the chickens of the twolined parental form SM79 can give a good egg productivity - 169 eggs per initial laying hen for 62 weeks of hens' life, of which 162.6 pieces can be used for incubation purposes and 138.5 heads of day-old broilers can be obtained.

The complex indicator - the meat yield from one parent pair was $314.8 \mathrm{~kg}$, which is $18.4 \%$ higher in comparison with the Smena- 8 cross. The accuracy of sexing of the day-old chicks according to the development of flight feathers and wing coverts is $99.8 \%$.

The results of testing broilers in the production conditions of the "Smena" SGC are presented in Table 3.
Table 3. Genetic potential of broilers of two crosses Smena-9 and Smena- 8 selected by "Smena" SGC.

\begin{tabular}{|l|c|c|c|}
\hline \multicolumn{1}{|c|}{ Traits } & $\begin{array}{c}\text { Smena- } \\
9\end{array}$ & $\begin{array}{c}\text { Smena- } \\
8\end{array}$ & $\begin{array}{c}\text { Smena-9 to } \\
\text { Smena-8, \% }\end{array}$ \\
\hline Slaughter age, days & 35 & 35 & \\
\hline $\begin{array}{l}\text { Live weight of the head } \\
\text { at 5-weeks age, g }\end{array}$ & 2273 & 2005 & +13.3 \\
\hline Average daily gain, g & 63.8 & 56.2 & +13.5 \\
\hline $\begin{array}{l}\text { Feed consumption, } \\
\mathrm{kg} / \mathrm{kg}\end{array}$ & 1.65 & 1.79 & -7.8 \\
\hline Livability, \% & 98.9 & 97.6 & +1.3 \\
\hline Dressed weight, \% & 73.0 & 71.5 & +1.5 \\
\hline Pectoral muscle yield, \% & 22.4 & 21.2 & +1.2 \\
\hline $\begin{array}{l}\text { Abdominal fat content, } \\
\%\end{array}$ & 1.19 & 1.41 & -0.22 \\
\hline Productivity index, units & 389 & 313 & +24.3 \\
\hline
\end{tabular}

In the process of selection of linear poultry, improved were the following characteristics of broilers: livability, live weight, dressed weight, pectoral muscle yield. The feed costs per $1 \mathrm{~kg}$ of live weight gain were reduced. The increase in meat yield was achieved mainly due to a 268 $\mathrm{g}$ increase of live weight of the 35-days-old final broiler hybrid (Table 2).

The genetic potential of broilers raised under optimal conditions of "Smena" SGC was $63.8 \mathrm{~g}$ of growth rate, $2273 \mathrm{~g}$ of live weight with feed consumption of $1.65 \mathrm{~kg}$ per kilogram of live weight gain, $22.4 \%$ of pectoral muscle yield. The uniformity of broilers of the Smena-9 cross in terms of live weight was $90 \%$ for cockerels and $88 \%$ for pullets.

Table 4 shows the meat qualities of broiler chicken carcasses of two Russian crosses Smena-9 and Smena-8.

Table 4. Meat quality of carcasses of 35-days-old broiler chickens.

\begin{tabular}{|c|c|c|c|}
\hline \multirow{2}{*}{ Characteristics } & \multicolumn{2}{|c|}{ Cross } & Smena-9 to \\
\cline { 2 - 3 } & Smena-8 & Smena-9 & Smena-8, \% \\
\hline $\begin{array}{c}\text { The yield of edible } \\
\text { parts in total,\% }\end{array}$ & 77.4 & 78.95 & +1.55 \\
\hline incl. muscles, \% & 64.0 & 65.8 & +1.8 \\
\hline $\begin{array}{c}\text { The yield of inedible } \\
\text { parts }\end{array}$ & 22.6 & 21.05 & -1.55 \\
\hline incl. bones, \% & 21.6 & 20.4 & -1.2 \\
\hline
\end{tabular}

The highest yield of edible parts was observed for broilers of the new Russian cross Smena-9 (78.95\% versus $77.4 \%$ for the Smena- 8 cross). This was achieved mainly due to the higher muscle yield in the chicken carcasses of the new cross $(65.8 \%$ versus $64.0 \%$ for the Smena- 8 cross). Accordingly, the yield of inedible parts in the carcasses of hybrid chickens of the new generation cross decreased by $1.55 \%$ (21.05\% versus $22.6 \%$ for the Smena- 8 cross), mainly due to a relative decrease in bone yield by $1.2 \%(20.4 \%$ versus $21.6 \%$ for the Smena8 cross).

Analysis of the results of a physicochemical study of poultry meat showed that the greatest amount of protein in white meat was found for the 49-days-old (22.6\%), and for the 35 -days-old it was $21.2 \%$. The same pattern for this indicator was noted in the leg quarters muscles ( $18.7 \%$ at 35 days versus $19.6 \%$ at 49 days). 
The amount of fat in the meat of the breasts and leg quarters decreased with age from 2.1 to $1.45 \%$. The ash content was in the range of $0.95-1.04 \%$.

The tasting assessment on a 5-point scale showed that the taste and aroma of the broth from poultry meat of the Smena-9 cross for the 49-days-oldwere rated at 4.89 points, which is $4.7 \%$ higher than for the 35 -daysold (4.67 points).

In the production conditions of poultry farms in the Russian Federation, the average daily growth of broilers was within $56.15-63.3 \mathrm{~g}$, feed costs per $1 \mathrm{~kg}$ of live weight gain were $1.60-1.75 \mathrm{~kg} / \mathrm{kg}$, broiler livability was $94.2-97.9 \%$, productivity index was $308-348$ units.

\section{Conclusions}

As a result of targeted breeding work with the use of various genetic material, a new Russian highly productive four-lined cross of meat chickens Smena-9 was created. It has an autosex maternal parental form for marker genes $K-k$ with a high accuracy of sexing of dayold chickens $(99.8 \%)$. The productivity of broiler parental herd is high, the dressed weight per parent pair is 314.8 (when growing broilers up to 5 weeks), which is $18.4 \%$ higher in comparison with the Smena- 8 cross. The broiler productivity index increased by $24.3 \%$. The taste qualities of broth and poultry meat of the Smena-9 cross are high.

Poultry of autosex for marker genes $K-k$ maternal parental form and broilers of the Smena- 9 cross can be successfully used in the production of eggs and meat at various enterprises.

\section{References}

1. L.I. Tuchemskiy, K.V. Zlochevskaya, V.I. Fisinin, G.V. Gladkova, Breeding of meat chickens of the state breeding plant "Smena", Sergiev Posad, 308 (2002)

2. A.V. Egorova, The main directions of work with meat chickens of broiler breeders, Pticevodstvo, 3, 16-21 (2017)

3. A.V. Egorova, L.I. Tuchemsky, Zh.V. Emanuylova, D.N. Efimov, Productivity of parental forms of meat chickens of breeding of the Selection Genetic Center "Smena", Zootehnia, 6, 2-4 (2015)

4. L.S. Karpenko, Improvement of Plymouth Rock Meat Chickens - Carriers of the Slow Feathering Gene, Proceedings of the III Int. Conf. "Poultry keeping - world and Russian experience", Moscow, Pishchepromizdat, 99 (2004)

5. T. Petrukovich, Separate growing of broilers, Livestock in Russia, 12, 11-12 (2017)

6. Ya.S. Roiter, A.V. Egorova, A.P. Konopleva, E.E. Tyapugin, G.V. Shashina, T.N. Degtyareva, L.S. Karpenko, V.M. Tyurikov, O.N. Petrukhin, N.G. Shcherbakova, Selection and breeding work in poultry, ed. by V.I. Fisinin, Ya.S. Roiter, Sergiev Posad, 287 (2016)
7. P.K. Bramwell, Sexing chicks in the backyard flock [Electronic resource], The Poultry Site Available at: http://www.thepoultrysite.com/articles/95/sexingchicks-in-the-backyard-flock/ (accessed: 02.12.2018)

8. Y.H. Cheng, T.E. Kuo, D.N. Lee, C.F. Weng, Sex identification of the Black-faced Spoonbill (Platalea minor), Zoological Studies, 45,104-113 (2006)

9. J. Zhao, J. Yao, F. Li, Z. Yang, Z. Sun, L. Qu, K. Wang, Y. Su, A. Zhang, S.A. Montgomery, T. Geng, H. Cui, Identification of candidate genes for chicken early - and late -feathering, Poultry $\begin{array}{lllll}\text { Sci., } & 95 & \text { (7), } 1498-1503 & \text { (2016) DOI: }\end{array}$ 10.3382/ps.pew131

10. G. Bu, G. Huang, H. Fu, J. Li, S. Huang, Y. Wang, Characterization of the novel duplicated PRLR gene at the late-feathering $\mathrm{K}$ locus in Lohmann chickens, J. Mol. Endocrinol., 51, 261276 (2013) DOI: 10.1530/jme-13-0068

11. L. Korshunova, Y. Royter, A. Egorova, The usage of gene modifiers in selection of new forms of color- and feather-sex poultry, Proc. XIV European Poultry Conference, 27 June 2014, Stavanger, Norway, 23-27 June 2014, Stavanger, 512 (2016)

12. Y. Royter, A. Egorova, A. Sevastianova, L. Korshunova, The selection of autosex interlinear forms of poultry (chicken, geese, Guinea fowl), Proc. XXV World's Poultry Congress, 5-9 Septeber 2016, China, Beijing, 257 (2016)

13. D.N. Efimov, Zh.V. Emanuylova, E.V. Zhuravleva, A.V. Egorova, V.I. Fisinin, Poultry breeding of the original lines of the Plymouth Rock (Gallus gallus L.) breed using marker genes K and к, Agricultural Biology, 53 (6), 1162-1168 (2018)

14. A.V. Egorova, L.V. Shakhnova, Separation of autosex meat chickens by sex, Poultry and Poultry Products, 3, 41-43 (2013)

15. I.A. Egorov, V.A. Manukyan, T.M. Okolelova, et all, Poultry feeding guide, Sergiev Posad, ARRTPI, 226 (2018)

16. V.S. Lukashenko, M.A. Lysenko, T.A. Stollar, A.Sh. Kavtarashvili, et all, Methodology for the anatomical cutting of carcasses, organoleptic assessment of the quality of meat and eggs of poultry and the morphology of eggs, Sergiev Posad, ARRTPI, 35 (2013). 